\title{
Setup of axial bearing capacity of open ended tubular steel piles driven in sand
}

https://doi.org/10.2478/sgem-2019-0032

received April 24, 2019; accepted September 18, 2019.

\begin{abstract}
This paper focuses on the setup of axial bearing capacity of open ended tubular steel piles that are used for offshore foundation systems such as those of wind turbines. A comparative evaluation of the most commonly used models for setup prediction shows an upper estimate bound and a lower estimate bound, which correspond approximately to a setup rate of $60 \%$ increase per log cycle of time and $20 \%$ increase per log cycle of time, respectively. This finding is validated with the results of case histories reported in literature, which show that the setup values of most case histories considered lie in the best estimate zone between the upper estimate zone and the lower estimate zone. The analysis results show a minimum setup factor of approximately 1.5 for 100 days following end of driving of open-ended tubular steel pile driven in sand.
\end{abstract}

Keywords: Setup, axial bearing capacity, driven open ended pile, granular soil, sand.

\section{Highlights}

- Detailed presentation of setup phenomenon in granular sand and contributing mechanisms

- Detailed presentation of setup prediction models in granular sand

- Demonstration of lower bound, best estimate bound and upper bound for setup prediction

\footnotetext{
*Corresponding author: Marx Ferdinand Ahlinhan, Department of Civil Engineering, ${ }^{1}$ National University of Sciences, Technologies, Engineering and Mathematics (UNSTIM), Abomey, Republic of Benin, E-mail: ahlinhan@yahoo.fr, ORCID number: https://orcid. org/0000-0003-0929-9849

Edmond Codjo Adjovi, Department of Civil Engineering, 1National University of Sciences, Technologies, Engineering and Mathematics (UNSTIM), Abomey, Republic of Benin
}

- Compilation of case histories of setup for driven open ended pile in granular soil and validation of lower estimate, best estimate and upper estimate zone

\section{List of Notations}

$A$ setup factor according to Skov and Denver (1998) expressing the increase rate per log cycle of time

B setup factor according to Svinkin et al. (1994)

CPT cone penetration test

a $\quad$ setup factor according to Long et al. (1999)

$\mathrm{Q}_{\mathrm{t}} \quad$ axial pile bearing capacity at time $\mathrm{t}$

$Q_{0} \quad$ axial pile bearing capacity at time $t_{0}$

EOD end of driving

EOID end of initial driving

$t \quad$ time elapsed after initial driving

$\mathrm{t}_{\mathrm{o}}$ reference time from which the increase in capacity is linear in logarithmic time scale

$\sigma_{\mathrm{rc}}^{\prime} \quad$ local radial effective stress

$\Delta \sigma_{\text {rd }}^{\prime} \quad$ dilatant increase in local radial effective stress during pile loading

$\delta_{c y} \quad$ interface angle of friction at failure

$\tau_{\mathrm{f}} \quad$ ultimate unit shaft friction

\section{Introduction}

Pile setup is defined as the increase of axial pile bearing capacity with time after its installation in soils. Pile setup is linked to some mechanisms such as the soil consolidation due to dissipation of excess pore water, soil ageing, corrosion or re-bonding and so on. Soil ageing is a process whereby recently disturbed or deposited soils gain stiffness and strength over time at constant effective stress. The ageing phenomenon often leads to an increase in the stiffness and strength of granular soils (Mitchell and Solymar (1984), Schmertmann (1991), Thomann and Hryciw (1992), Ng et al. (1998)). However, in a few cases, a reduction in pile capacity with time was reported (Bullock et al. (2005)). This reduction in pile capacity with time 
occurs primarily because of the dissipation of negative pore pressures due to pile driving. Chow et al. (1998) reported three soil profiles that may create this condition: strong soils that dilate during penetration, weak sediment and metamorphic rock, and sands confined by a cofferdam or closely spaced pile. The soil leading to a decrease in pile capacity with time is termed as sensitive by Mitchell and Solymar (1984), Mitchell (1986), York et al. (1994). The setup phenomenon linked to ageing and the increase of pile bearing capacity driven in granular soil has been observed in the field tests by Chow (1997), Skow and Denver (1998), Jardine and Standing (1999), Kirsch and von Bargen (2012); Ciavaglia et al. (2017). Pile axial capacities have been found to typically double over 6 months, although this effect is variable. The process of the setup has been found to continue for up to 5 years, long after pore pressures have dissipated (Browman and Soga (2005)).

This paper describes the setup phenomenon and the mechanisms that lead to setup in granular soils for better understanding of the setup phenomenon. Furthermore, a comparative study is carried out for the most common used models for setup prediction. The results obtained from this comparison study are validated with pile cases history.

\section{Mechanism Of Setup In Granular Soil}

When a pile is driven, a volume of soil approximately equal to the volume of pile is displaced during the installation. This soil displacement generally occurs in the direction of least resistance. For example, in normally consolidated or overconsolidated sand, the horizontal (radial) stress is generally lower than the vertical stress during the pile driving. Therefore, soil is displaced predominately radially along the pile shaft, and vertically and radially beneath the toe. However, some vertical displacement along the shaft may also occur. This displacement can significantly alter the stress in the soil. The soil below and adjacent to the pile undergoes a high degree of shearing, Bowman and Soga (2005), Jardine et al. (2006) and Chow et al. (1998). Randolph et al. (1979) states that in clay, pile driving can significantly alter the stress in the soil up to approximately 20 pile radii. As soil around and beneath the pile is displaced and disturbed, it forms an arching around the pile, thereby generating excess pore water pressures, thus decreasing the effective stress of the soil.
As a result, the radial stress around the pile decreases. Hence, the pile shaft resistance also decreases. The ultimate unit shaft friction $\tau_{f}$ developed on a pile in sand follows the Coulomb failure criterion, Lehane et al. (1993), Jardine et al. (2005):

$$
\tau_{f}=\left(\sigma_{r c}^{\prime}+\Delta \sigma_{r d}^{\prime}\right) \tan \delta_{c v}
$$

$\sigma_{\mathrm{rc}}^{\prime}=$ local radial effective stress; $\delta_{\mathrm{cv}}=$ interface angle of friction at failure; $\Delta \sigma_{\mathrm{rd}}=$ dilatant increase in local radial effective stress during pile loading.

However, Boulon and Foray (1986) stated that changes in lateral stress during loading are quite uncertain, but appear to result from constrained dilation, which can be modelled using a cylindrical cavity expansion analogy.

The phenomenon of the setup in granular soil can be divided into four (4) time-dependent interrelated mechanisms, based on the results of Schmertmann (1991), Chow et al. (1996) and Axelson (2000), Jardine et al. (2013):

- Dissipation of excess pore water pressure during the primary consolidation

- Creep induced relaxation of the soil arch that leads to breakdown of the arching stress and increases in radial stress, hence gains in shaft capacity

- Soil ageing leading to an increase in dilatancy, strength and stiffness of the soil. This leads to large radial effective stresses acting to the pile shaft during loading.

- Chemical corrosion or re-bonding resulting in an increase in surface roughness and interface angle between pile material and soil $\left(\delta_{\mathrm{cv}}\right)$

- Mechanical or thermal constrained dilatancy that leads to the increase of the radial effective stresses acting to the pile shaft during loading.

However, changes in stationary radial stress during set-up and enhanced dilation during loading appear to be the principal mechanisms controlling the pile ageing in sand (Gavin et al. (2015)). The setup is initiated by the dissipation of excess pore water pressure during the primary consolidation. The excess pore water pressure induced by pile installation can be dissipated in approximately 2 days after the end of driving in sand (Bullock et al. (2005)). The dissipation of excess pore pressure increases the radial effective stress, and therefore the ultimate unit shaft friction. The pile setup due to primary consolidation is termed as short-term setup (Axelsson (2000), Augustesen et al (2006)). The long-term setup is characterized by creep induced relaxation of soil arching, soil ageing and chemical corrosion of pile material. Creep-induced 

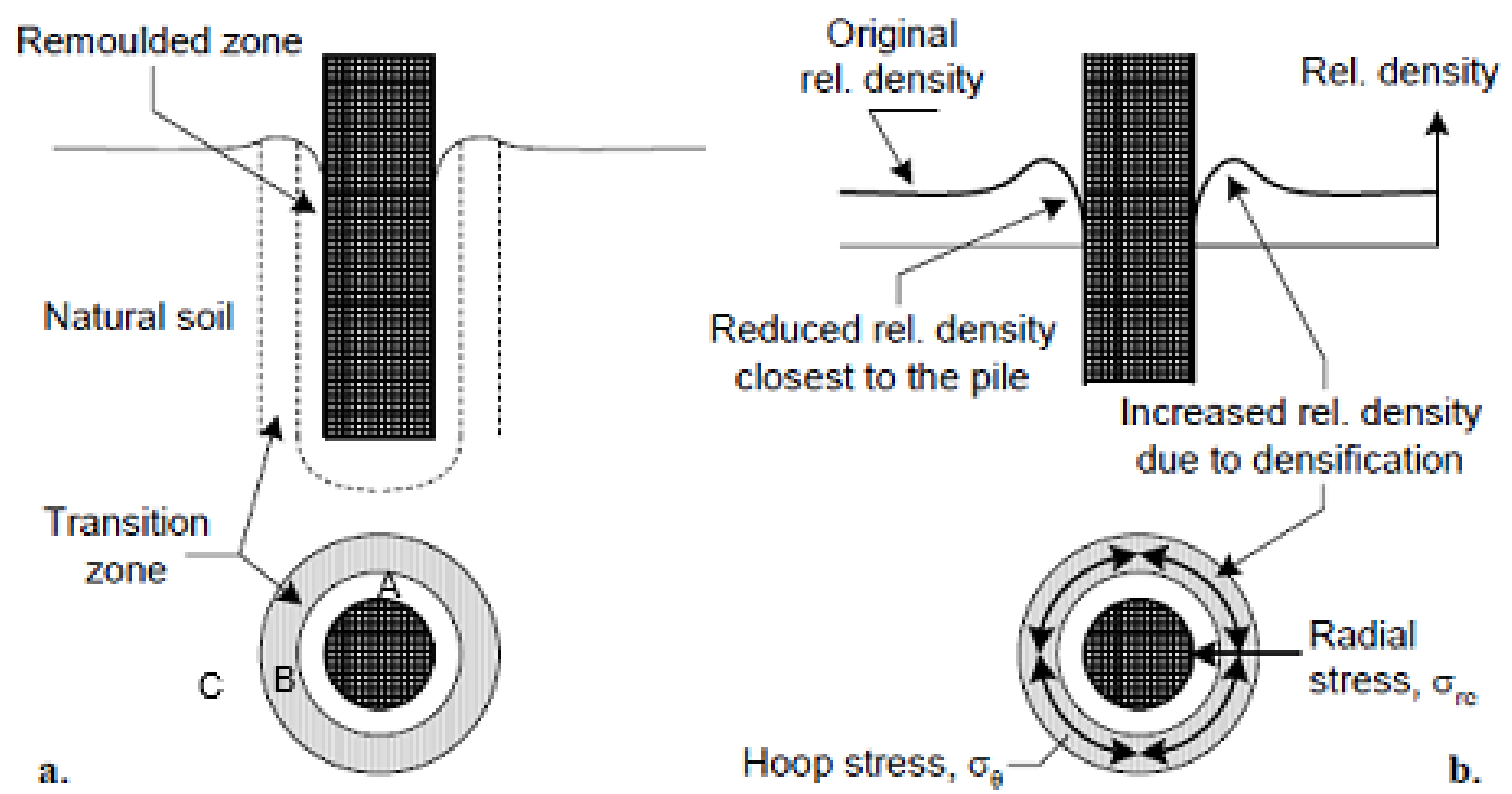

Figure 1: a) Zones created during pile driving, b) relative density in the soil and arching mechanisms around the pile shaft due to pile driving (Augustesen et al (2005))

relaxation of the arching may additionally decrease the excess pore water pressure. Figure 1 is taken from the paper by Augustesen et al. (2005) and annotated with additional points $\mathrm{A}, \mathrm{B}$ and $\mathrm{C}$ by the authors of the present paper:

(i) Zone A represents the remoulded soil adjacent to the pile (Ciavaglia et al. (2017)). In this zone, the soil is altered by the pile driving process that leads to the accumulation of excess pore water pressure. As a result, the radial effective stress is lower in comparison to the original natural soil in zone $\mathrm{C}$, which is not disturbed by the pile driving process.

(ii) Zone $\mathrm{B}$ represents a transition zone with arching soils developed during the pile driving process (Chow et al. (1998), Browman and Soga (2005)). Some soil blocks show hoop stresses and form soil arching in this zone. Creep induced relaxation leads to breakdown of soil arching. As a result, the effective radial stress increases.

(iii) Zone $\mathrm{C}$ is not disturbed by the pile driving process.

\section{Setup Prediction Models And Comparison}

Adequate time to assess the setup after the end of the driving depends on the soil type, the degree of the soil disturbance, the ability of the soil to dissipate the excess pore water pressure (hydraulic conductivity), the coefficient of radial (horizontal) consolidation, the pile diameter, and the soil layering. Therefore, there is no general agreement regarding the adequate time to assess the setup.

In engineering practice, particularly in offshore industry, long delays between end-of-driving and restrike testing are not always possible or practicable. Therefore, some empirical, semi-empirical, and analytical models have been proposed by researchers to predict pile setup with time (Skov and Denver (1988), Svinkin et al. (1994) and Long et al. (1999), Svinkin and Skov (2000)). Most of these empirical equations were developed based on a limited database, and therefore, site specific (or local) calibration may be essential for best prediction. Table 1 presents a summary of the commonly used models for the prediction of the setup in sand. The value $A, B$ and $\alpha$ are assumed to be dependent only on the soil type. Based on the different mechanisms of the set-up phenomenon described in section 2, it can be believed that the value of $A$ would depend also on the pile type, the pile geometry, the driving method, the overconsolidation ratio of the soil, and other soil properties.

Figure 2 presents a comparison of the setup prediction models. It can be seen that the results of these prediction models show the best estimate zone lying between the upper estimate zone and the lower estimate zone. The upper estimate bound represents a setup rate of approximately $60 \%$ increase per log cycle of time, 


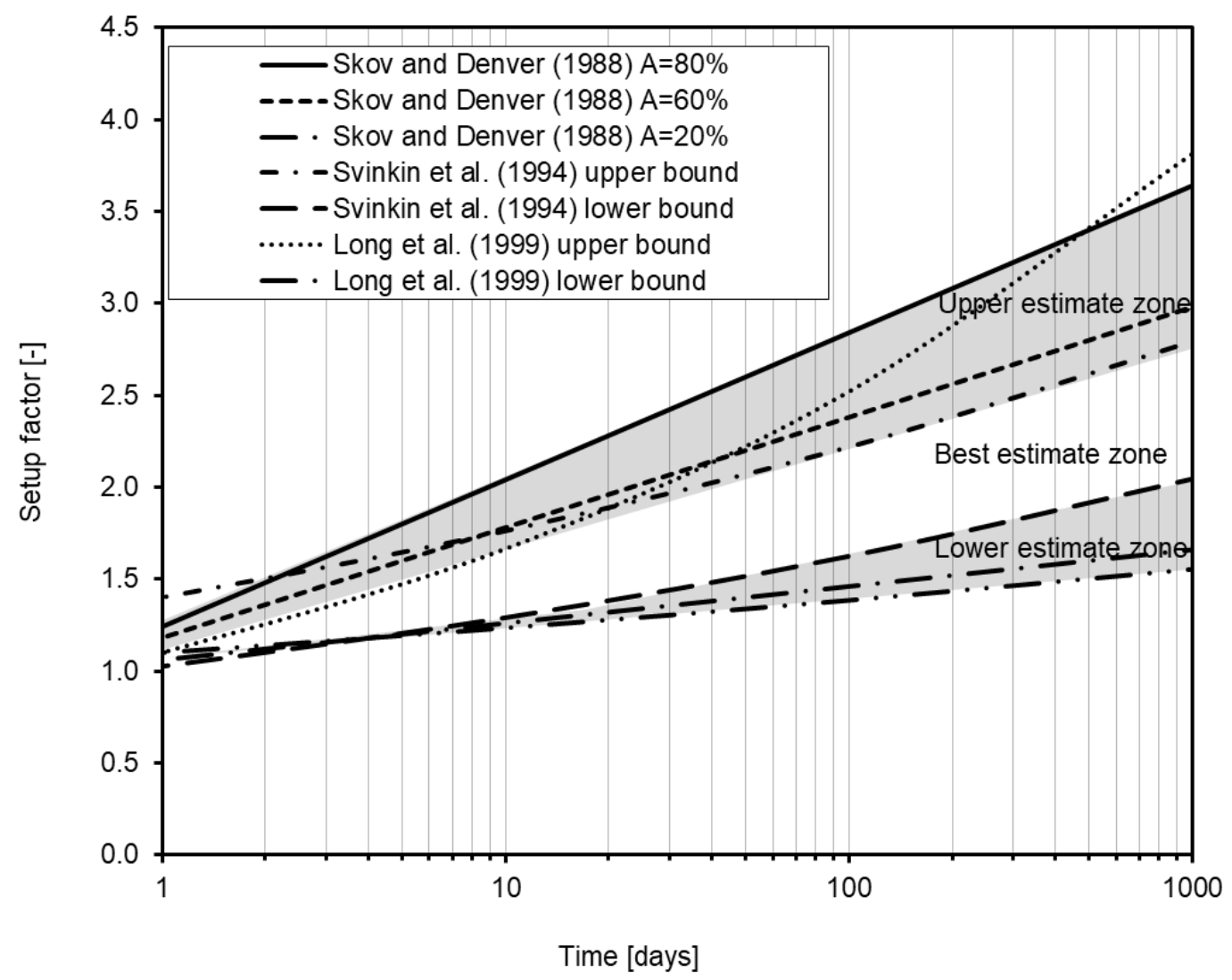

Figure 2: Comparison of results of setup prediction models in sand

Table 1: Empirical models for predicting increase in bearing with time

\begin{tabular}{lll}
\hline References & Equation & Comments \\
\hline $\begin{array}{l}\text { Skov and } \\
\text { Denver (1998) }\end{array}$ & $Q_{t}=Q_{0}\left(1+A \log t / t_{0}\right)$ & $t_{0}=0.5$ and $A=0.2$ for sand \\
Svinkin et al. & $Q_{t}=B Q_{E O D} t^{0.1}$ & $B=1.4$ upper bound \\
(1994) & & $B=1.025$ lower bound \\
Long et al. & $Q_{t}=1.1 Q_{E O D} t^{\alpha}$ & $\begin{array}{l}\alpha=0.18 \text { for upper bound value } \\
\text { (1999) }\end{array}$ \\
& & $\begin{array}{l}\alpha=0.13 \text { for average value } \\
\alpha=0.05 \text { for lower bound value }\end{array}$ \\
&
\end{tabular}

while the lower estimate bound represents a step rate of approximately $20 \%$ increase per log cycle of time.

The results of case histories of open ended tubular piles driven in sand have been compiled in Table 2. Data obtained from offshore pile driving is scarce as most researches are carried onshore for practical reasons. However, Bowman and Soga (2005), Rimoy et al. (2015) stated that water has little influence on pile setup, especially in sands, since pore water pressures dissipate almost immediately and effective stresses govern pile capacity (Gavin et al. (2015)). Therefore, results of onshore and offshore tests should be comparable. Nevertheless, it should be noted that cycling of the water table (in onshore tests) may increase set-up rates (Bowman and Soga (2005), White and Zhao (2006)).

The results of these case histories are plotted in the semi-logarithmic setup time diagram.

Figure 3 shows that the most case histories lie within the best estimate zone. Therefore, the upper estimate, lower estimate and the best estimate zones obtained from the comparative evaluation can be assumed to be validated by the results of case histories considered. However, few results of case histories lie out of the lower and upper estimate zones that can be explained by the quality of pile testing results or the non-consideration of the pile geometry, pile material, particle shape, particle strength, overconsolidation ratio, relative density of sand etc.

Figure 3 shows a minimum setup factor of approximately 1.5 for 100 days following end of driving of open ended tubular steel pile driven in sand. That is valid for pile subjected to predominantly axial loading. Results of model tests by Ciavaglia (2017) showed that the ultimate shaft resistance can be affected by previous lateral loading. While the application of lateral loads up to 
Table 2: Compilation of case histories for open-ended tubular piles driven in sand

\begin{tabular}{|c|c|c|c|c|c|c|c|c|c|}
\hline Reference & $\begin{array}{l}\text { Test locat } \\
\text { ion }\end{array}$ & $\begin{array}{l}\text { Soil } \\
\text { description }\end{array}$ & $\begin{array}{l}\text { CPT cone } \\
\text { resistance qc } \\
(\mathrm{MPa})\end{array}$ & Pile diameter & Pile & Wall & $\begin{array}{l}\text { Static / } \\
\text { dynamic }\end{array}$ & Max & Results \\
\hline & & & & (m) & $\begin{array}{l}\text { Length } \\
(\mathrm{m})\end{array}$ & $\begin{array}{l}\text { thickness } \\
(\mathrm{mm})\end{array}$ & testing & time (d) & \\
\hline Skov and & $\begin{array}{l}\text { Südkai, } \\
\text { Hamburg, }\end{array}$ & $\begin{array}{l}\text { alternating } \\
\text { layers of fine, }\end{array}$ & - & 0.762 & 33.7 & 12.7 & $\begin{array}{l}\text { dynamic } \\
\text { and }\end{array}$ & 30 & $\begin{array}{l}42 \% \text { increase } \\
\text { in total } \\
\text { capacity, }\end{array}$ \\
\hline $\begin{array}{l}\text { Denver } \\
(1988)\end{array}$ & Germany & $\begin{array}{l}\text { medium and } \\
\text { coarse sand, } \\
\text { locally with } \\
\text { fine gravel }\end{array}$ & & & & & $\begin{array}{l}\text { static } \\
\text { testing }\end{array}$ & & $\begin{array}{l}\text { derived from } \\
\text { CAPWAP } \\
\text { analysis of init } \\
\text { ial driving and } \\
\text { a restrike test } \\
\text { after } 30 \text { days }\end{array}$ \\
\hline \multirow[t]{2}{*}{$\begin{array}{l}\text { Shioi et al. } \\
\text { (1992) }\end{array}$} & $\begin{array}{l}\text { Trans Tokyo } \\
\text { Bay }\end{array}$ & $\begin{array}{l}\text { alternating } \\
\text { layers of }\end{array}$ & 40 & 2 & 62 & $31-34$ & $\begin{array}{l}\text { dynamic } \\
\text { and }\end{array}$ & 50 & $\begin{array}{l}\text { set-up fact } \\
\text { or of approx. } \\
2 \text { on }\end{array}$ \\
\hline & $\begin{array}{l}\text { Highway, } \\
\text { Japan }\end{array}$ & $\begin{array}{l}\text { cohesive } \\
\text { soil and very } \\
\text { dense sand }\end{array}$ & & & & & $\begin{array}{l}\text { static } \\
\text { testing }\end{array}$ & & $\begin{array}{l}\text { total resist } \\
\text { ance was } \\
\text { measured }\end{array}$ \\
\hline \multirow[t]{3}{*}{$\begin{array}{l}\text { York et al. } \\
\text { (1994) }\end{array}$} & $\begin{array}{l}\text { JFK Airport, } \\
\text { New }\end{array}$ & $\begin{array}{l}\text { medium } \\
\text { dense, } \\
\text { medium- }\end{array}$ & - & 0.355 and & 20 & $5.3-6.1$ & $\begin{array}{l}\text { dynamic } \\
\text { and }\end{array}$ & 49 & $\begin{array}{l}\text { increase in } \\
\text { pile capacity } \\
\text { of } 40 \text { - }\end{array}$ \\
\hline & York, USA & $\begin{array}{l}\text { fine glacial } \\
\text { sand; 2m } \\
\text { thick clay and } \\
\text { peat layer near } \\
\text { surface }\end{array}$ & & 0.2 & & & $\begin{array}{l}\text { static } \\
\text { testing }\end{array}$ & & $\begin{array}{l}75 \% \text { occurred } \\
\text { because of } \\
\text { set- up }\end{array}$ \\
\hline & & & & $\begin{array}{l}\text { (tapered } \\
\text { monotube } \\
\text { piles) }\end{array}$ & & & & & \\
\hline $\begin{array}{l}\text { Fellenius } \\
\text { and }\end{array}$ & $\begin{array}{l}\text { North S } \\
\text { hore, }\end{array}$ & $\begin{array}{l}2 \mathrm{~m} \text { of sand } \\
\text { and gravel fill }\end{array}$ & - & 0.324 and & 16.5 & 12.5 and 9 & $\begin{array}{l}\text { dynamic t } \\
\text { esting }\end{array}$ & 71 & $\begin{array}{l}\text { total pile } \\
\text { capacity }\end{array}$ \\
\hline $\begin{array}{l}\text { Altaee } \\
(2002)\end{array}$ & $\begin{array}{l}\text { Vancouver, } \\
\text { Canada }\end{array}$ & $\begin{array}{l}\text { on top of silt } \\
\text { y sand, sandy } \\
\text { silt and dense } \\
\text { "till like" silt } \\
\text { and sand }\end{array}$ & & 0.457 & & & & & $\begin{array}{l}\text { approximately } \\
\text { doubled bet } \\
\text { ween } \\
1 \text { and } 30 \text { days } \\
\text { after driving }\end{array}$ \\
\hline \multirow[t]{2}{*}{$\begin{array}{l}\text { Bhushan } \\
\text { (2004) }\end{array}$} & $\begin{array}{l}\text { LAXT wharf, } \\
\text { Los }\end{array}$ & $\begin{array}{l}\text { medium dense } \\
\text { to very }\end{array}$ & & 0.91 and 1.37 & $\begin{array}{l}33.5- \\
41.5\end{array}$ & $16-25$ & $\begin{array}{l}\text { dynamic t } \\
\text { esting }\end{array}$ & 139 & $\begin{array}{l}\text { a set-up of } \\
1.2 \text { to } \\
1.5 \text { for }\end{array}$ \\
\hline & $\begin{array}{l}\text { Angeles, } \\
\text { USA }\end{array}$ & $\begin{array}{l}\text { dense sands } \\
\text { inter-layered } \\
\text { with clay } \\
\text { and silt layers }\end{array}$ & $\begin{array}{l}1 \text { in clayey silt } \\
\text { s, } 7 \text { to } 33 \text { in } \\
\text { sands }\end{array}$ & & & & & & $\begin{array}{l}\text { periods of } 1 \mathrm{t} \\
010 \text { days and } \\
1.6\end{array}$ \\
\hline
\end{tabular}


Table 2: Compilation of case histories for open-ended tubular piles driven in sand

\begin{tabular}{|c|c|c|c|c|c|c|c|c|c|}
\hline Reference & $\begin{array}{l}\text { Test locat } \\
\text { ion }\end{array}$ & $\begin{array}{l}\text { Soil } \\
\text { description }\end{array}$ & $\begin{array}{l}\text { CPT cone } \\
\text { resistance qc } \\
(\mathrm{MPa})\end{array}$ & Pile diameter & Pile & Wall & $\begin{array}{l}\text { Static / } \\
\text { dynamic }\end{array}$ & Max & Results \\
\hline & & & & & & & & & $\begin{array}{l}\text { to } 2 \text { for } \\
\text { periods } \\
\text { from } 14 \text { to } \\
139 \text { days }\end{array}$ \\
\hline \multirow[t]{2}{*}{$\begin{array}{l}\text { Kolk et al. } \\
(2005)\end{array}$} & $\begin{array}{l}\text { Eemshav } \\
\text { en, }\end{array}$ & $\begin{array}{l}\text { silty to very } \\
\text { silty, medium } \\
\text { to }\end{array}$ & 40 to 80 & 0.76 & $\begin{array}{l}\text { up to } \\
47 \mathrm{~m}\end{array}$ & $36-42$ & $\begin{array}{l}\text { dynamic } \\
\text { (during }\end{array}$ & 533 & $\begin{array}{l}\text { total capacity } \\
\text { increase of at }\end{array}$ \\
\hline & $\begin{array}{l}\text { Net } \\
\text { herlands } \\
\text { (EURIPIDES } \\
\text { JIP) }\end{array}$ & $\begin{array}{l}\text { very dense, } \\
\text { fine to } \\
\text { medium sands }\end{array}$ & & & & & $\begin{array}{l}\text { driving) } \\
\text { and static } \\
\text { testing }\end{array}$ & & $\begin{array}{l}\text { least } 1.5 \text { aft } \\
\text { er } 533 \text { days, } \\
\text { compared to } \\
\text { capacity after } \\
6 \text { days }\end{array}$ \\
\hline $\begin{array}{l}\text { Jardine et } \\
\text { al. (2006) }\end{array}$ & $\begin{array}{l}\text { Dunkirkt } \\
\text { est piles, }\end{array}$ & $\begin{array}{l}\text { dense to } \\
\text { very dense } \\
\text { marine }\end{array}$ & 10 to 20 & 0.324 and & Nov 22 & $13-20$ & static and & 1991 & $\begin{array}{l}100 \% \text { incre- } \\
\text { ase in shaft }\end{array}$ \\
\hline $\begin{array}{l}\text { and Chow et } \\
\text { al. (1998) }\end{array}$ & France & sand & & 0.457 & & & dynamic & & $\begin{array}{l}\text { capacity } 8 \\
\text { months after } \\
\text { driving. } 85 \% \\
\text { increase bet } \\
\text { ween } \\
6 \text { months and } \\
5 \text { years. }\end{array}$ \\
\hline \multirow[t]{2}{*}{$\begin{array}{l}\text { Rücker et } \\
\text { al. (2012) }\end{array}$} & $\begin{array}{l}\text { BAM } \\
\text { Horstwalde }\end{array}$ & sand & 16 & 0.711 & 18 & - & $\begin{array}{l}\text { dynamic } t \\
\text { esting }\end{array}$ & 30 & $\begin{array}{l}\text { between } 11 \text { - } \\
14 \% \\
\text { gain in }\end{array}$ \\
\hline & $\begin{array}{l}\text { test site, } \\
\text { Germany }\end{array}$ & & & & & & & & $\begin{array}{l}\text { capacity after } \\
10- \\
30 \text { days }\end{array}$ \\
\hline Kirsch and & $\begin{array}{l}\text { Nordsee } \\
\text { Ost }\end{array}$ & $\begin{array}{l}\text { Predominant } \\
\text { ly dense sand, }\end{array}$ & - & 2.438 & 35 & - & $\begin{array}{l}\text { dynamic t } \\
\text { esting }\end{array}$ & 31 & $\begin{array}{l}\text { reported set } \\
\text {-up factor of } \\
1.5\end{array}$ \\
\hline $\begin{array}{l}\text { von Bargen } \\
\text { (2012) }\end{array}$ & $\begin{array}{l}\text { offshore } \\
\text { wind farm, } \\
\text { North Sea }\end{array}$ & $\begin{array}{l}\text { (silty) sand } \\
\text { with thin clay } \\
\text { layers above } \\
26 \mathrm{~m}\end{array}$ & & & & & & & $\begin{array}{l}\text { after } 31 \text { days } \\
\text { of ageing }\end{array}$ \\
\hline \multirow[t]{2}{*}{$\begin{array}{l}\text { Gavin et al. } \\
\text { (2013) }\end{array}$} & $\begin{array}{l}\text { Blessingt } \\
\text { on, }\end{array}$ & $\begin{array}{l}\text { very dense, } \\
\text { glacially }\end{array}$ & 10 to 20 & 0.34 & 7 & 14 & $\begin{array}{l}\text { Static } \\
\text { tensiont } \\
\text { est }\end{array}$ & 220 & $\begin{array}{l}\text { pile capacity } \\
\text { increased by }\end{array}$ \\
\hline & Ireland & $\begin{array}{l}\text { deposited fine } \\
\text { sand }\end{array}$ & & & & & & & $\begin{array}{l}185 \% \text { over } \\
220 \text { days }\end{array}$ \\
\hline Reddy and & $\begin{array}{l}\text { Puget S } \\
\text { ound } \\
\text { Lowlands }\end{array}$ & & - & 0.36 & 8.7 & & $\begin{array}{l}\text { dynamic t } \\
\text { esting }\end{array}$ & 0.23 & $\begin{array}{l}\text { reported set } \\
\text {-up factor of } \\
1.0 \text { to } 4.0\end{array}$ \\
\hline $\begin{array}{l}\text { Stuedlein } \\
(2014)\end{array}$ & & Silt, Till & & 0.91 & 48.8 & & & 13 & \\
\hline
\end{tabular}




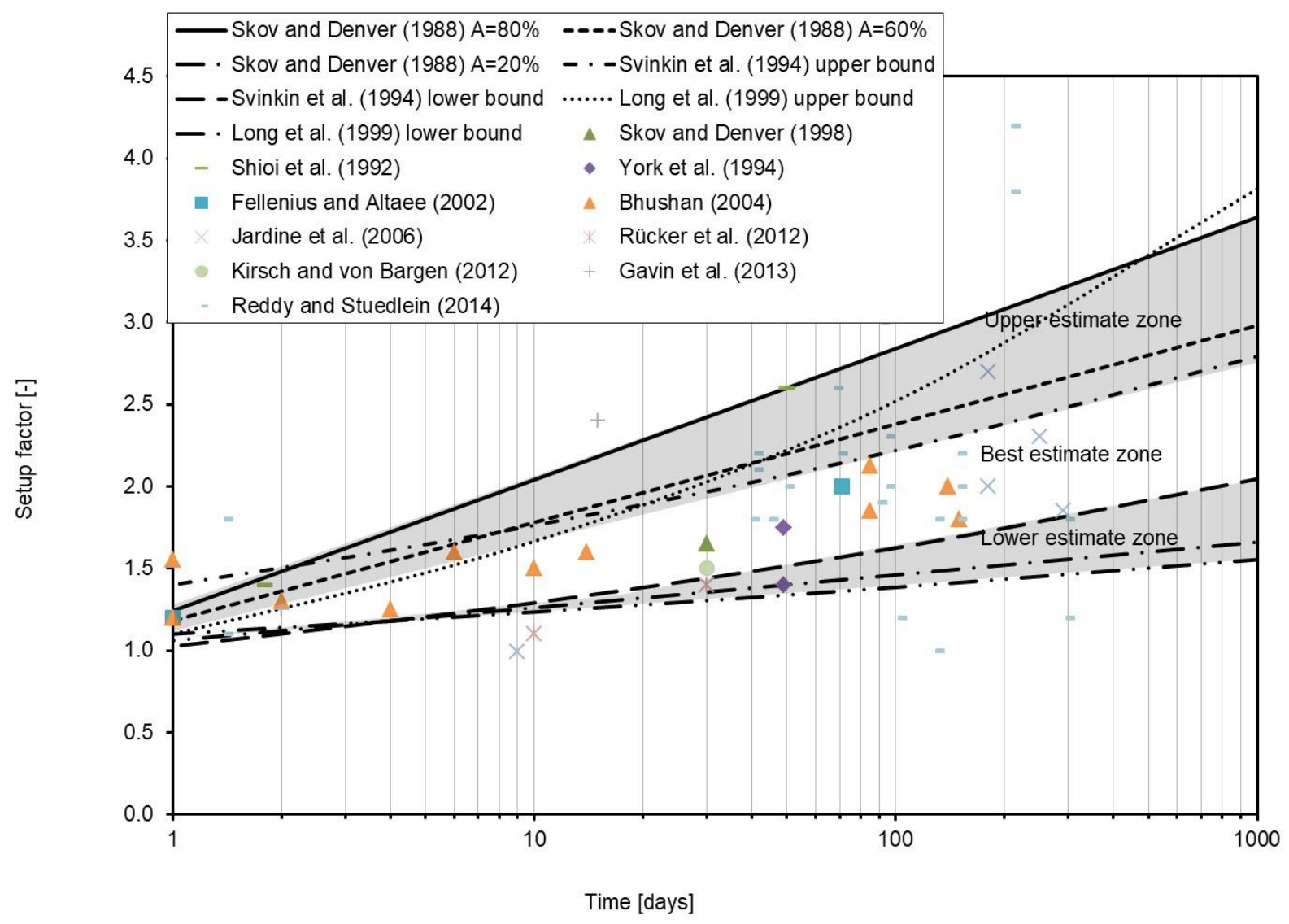

Figure 3: Compilation of pile cases history in predominately sand layer

$10 \%$ of the ultimate lateral resistance did not affect axial pile resistance, lateral loads reaching $50 \%$ of the ultimate lateral pile resistance resulted in a $65 \%$ reduction in ultimate shaft resistance relative to a pile that experienced no previous lateral loading (Ciavaglia (2017)). The increase of the axial pile capacity in the first hours after the end of driving is mainly controlled by the dissipation of the excess pore induced by the driving process. Therefore, it can be deduced that this short-term increase of pile capacity decreases with increasing pile diameter, since the degree of the pore water accumulation and the rate of the radial consolidation (pore water dissipation) are expected to be increased with increasing pile diameter. However, some of the mechanisms that contribute to longterm setup (e.g., soil creep and dilation, and soil stiffness increase with ageing) do not depend on the pile diameter (Bowman and Soga (2005); Rimoy and Jardine (2015)). Therefore, it can be concluded that the pile diameter influences particularly the short-term setup characterized by the dissipation of excess pore water pressure due to primary consolidation. The larger the pile diameter, the larger the driving induced excess pore water pressure will be.
It was found that low amplitude cyclic loading could accelerate axial pile capacity at a greater rate than no cyclic loading (White and Zhao (2006)). Jardine et al. (2006) also observed this phenomenon and it is confirmed by the creep tests performed by Bowman and Soga (2005). The increase of setup rate at low cyclic loading can be explained by accelerated, kinematically restrained dilatant of the soil surrounding the pile under compression creep (Bowman and Soga (2005)). Therefore, it can be recommended to drive the offshore pile in summer mainly characterized by low cyclic amplitude of waves in order to accelerate the rate of pile setup.

\section{Conclusions}

This paper described the mechanisms behind the setup of open-ended tubular piles driven in granular soils.

A comparative evaluation of the most commonly used models shows that the results of the setup prediction provide an upper estimate bound and a lower estimate bound, which correspond approximately to a setup rate of 
$60 \%$ increase per log cycle of time and $20 \%$ increase per log cycle per time, respectively. This finding is validated with the results of case histories reported in literature, which shows that the setup values of the most case histories lie in the best estimate zone between the upper estimate zone and the lower estimate bound zone. The analysis results show a minimum setup factor of approximately 1.5 after a delay of 100 days from the end of driving of open ended tubular steel pile driven in sand.

It is recommended to drive the offshore piles in summer because of the beneficial effect of the less cyclic wave loading that can accelerate the setup. Significant cost reductions in projects involving pile foundations in sand can be realized by taking pile setup into account.

\section{References}

[1] Augustesen, A., Andersen, L., Sørensen, C.S. (2005). Capacity of Piles in Sand. Published in: Department of Civil Engineering, Aalborg University, Denmark, Internal report, ISSN: 1398-6465 R0519.

[2] Augustesen, A., Andersen, L., Sørensen, C.S. (2006). Assessment of Time Functions for Piles Driven in Clay. Published in: Department of Civil Engineering, Aalborg University, Denmark, DCE Technical Memorandum No.1, ISSN: 1901-7278.

[3] Axelsson, G. (2000). Long-Term Set-Up of Driven Piles in Sand. No. TRITA-AMI PHD 1035 ISSN 1400-1284 ISRNKTH/AMI/PHD-1035--SE).

[4] Boulon, M., Foray, P. (1986) Physical and numerical simulation of lateral shaft friction of offshore piles in sand. Proceedings of the 3rd International Conference on Numerical Methods in Offshore Piling, Nantes, France, pp. 127-148.

[5] Bhushan, K. (2004). Design and Installation of Large Diameter Pipe Piles for LAXT Wharf. Geotech. Spec. Publ. Pract. Future Trends Deep Found. 125, pp. 370-389.

[6] Bowman, E.T., Soga, K., 2005. Mechanisms of setup of displacement piles in sand: laboratory creep tests. Can. Geotech. J. 42, 1391-1407.

[7] Bullock, P. J., Schmertmann, J. H., McVay, M. C., Townsend, F. C. (2005). Side shear setup. I: Test Piles Driven in Florida. Geotechnical and Geoenvironmental Engineering, 131(3), pp. 292-300.

[8] Bullock, P. J., Schmertmann, J. H., McVay, M. C., Townsend, F. C. (2005). Side shear setup. II: Test Piles Driven in Florida. Geotechnical and Geoenvironmental Engineering, 131(3), pp. 301-310.

[9] Chow, F.C., Jardine, R.J., Brucy, F., Nauroy, J.F., 1998. Effects of time on capacity of pipe piles in dense marine sand. J. Geotech. Geoenvironmental Eng. 124, 254-264.

[10] Ciavaglia, F., Carey, J., Diambra, A. (2017). Time-dependent uplift capacity of driven piles in low to medium density chalk. Géotechnique Letters, 7(1), pp. 90-96.

[11] Gavin, K., Jardine, R., Karlsrud, K., Lehane, B. (2015). The effects of pile aging on the shaft capacity of offshore piles in sand. Proc. Frontiers in offshore geotechnics III, ISBN 9781138028487 - CAT\# K26766

[12] Jardine, R.J., and Standing, J.R. 1999. Pile load testing performed for HSE cyclic loading study at Dunkirk, France. Vol. 1. UK. Health and Safety Executive, London, UK. Offshore Technology Report OTO 2000007.

[13] Jardine, R., Chow, F., Overy, R., Standing, J., 2005. ICP design methods for driven piles in sands and clays. Thomas Telford.

[14] Jardine, R.J., Standing, J.R., Chow, F.C., 2006. Some observations of the effects of time on the capacity of piles driven in sand. Géotechnique 56, 227-244.

[15] Jardine, R.J., Zhu, B.T., Foray, P., Yang, Z.X. 2013. Measurement of stresses around closed-ended displacement piles in sand. Géotechnique 63,1,1-17.

[16] Kirsch, F., von Bargen, M., 2012. Offshore Windpark Nordsee Ost - Sichere Grundung bei Wind und Welle. Presented at the Baugrundtagung Mainz.

[17] Karlsrud, K., Haugen, T. (1985). Axial static capacity of steel model piles in overconsolidated clays. Proc., 11th int. conf. on Soil Mechanics and Foundation Engineering, Balkema, Brookfield, Vt, 3, pp. 1401-1406.

[18] Kolk, H., Vergobbi, P., Baaijens, A., 2005. Results from axial load tests on pipe piles in very dense sands: the EURIPIDES JIP, in: Frontiers in Offshore Geotechnics: ISFOG 2005.

[19] Rücker, W., Baessler, M., Cuellar, P., Georgi, S., Richter, T., Kirsch, F., Savidis, S., Tasan, E., 2012. Anwendungsorientiertes Bemessungs- und Überwachungsmodell für Pfahlgründungen von Offshore-Windenergieanlagen unter zyklischer Belastung.

[20] Lehane, B.M., Jardine, R.J., Bond, A.J., Frank, R. (1993). Mechanisms of shaft friction in sand from instrumented pile tests. Journal of Geotechnical Engineering 119 (1), 19-35.

[21] Mitchell, J. K. (1986). Practical problems from surprising soil behavior. J. Geotech. Engrg., ASCE, 112(3), 259-289.

[22] Mitchell, J.K., and Solymar, Z.V. 1984. Time-dependent strength gain in freshly deposited or densified sand. Journal of Geotechnical Engineering, ASCE, 110(11): 1559-1576.

[23] Schmertmann, J.H., 1991. The mechanical aging of soils. ASCE J. Geotech. Eng. 117 (9), 1288-1330.

[24] Ng, E.S., Tsang, S.K., and Auld, B.C. 1988. Pile foundation: the behavior of piles in cohesionless soils. Federal Highway Administration, Washington, D.C. Report FHWA-RD-88-081.

[25] Ng, N., Berner, P., and Covil, C. 1998. The ageing effects of sands. Ground Engineering, 10(Suppl.): 21.

[26] Shioi, Y., Yoshida, O., Meta, T., Homma, M., 1992. Estimation of bearing capacity of steel pipe pile by static loading and stresswave theory (Trans-Tokyo Bay Highway). Presented at the Application of stress-wave theory to piles, pp. 325-330.

[27] Skov, R., Denver, H., 1988. Time-dependence of bearing capacity of piles, in: Proc. Third International Conference on the Application of Stress-Wave Theory to Piles. Ottawa. pp. 25-27.

[28] Svinkin, M.R., Skov,R. (2000).Set-up effect of cohesive soils in pile capacity. In:The 6th International Conference on Application of Stress-wave Theory to Piles. Sao Paulo, Brazil, pp.107-111.

[29] Thomann, T.G., and Hryciw, R.D. 1992. Stiffness and strength changes in cohesionless soils due to disturbance. Canadian Geotechnical Journal, 29(5): 853-861.

[30] White, D.J., Zhao, Y., 2006. A model-scale investigation into "set-up" of displacement piles in sand, in: Proceedings of 
the Sixth International Conference on Physical Modelling in Geotechnics-6th ICPMG. pp. 889-894.

[31] York, D.L., Brusey, W.., Clemente, F.M., Law, S.K., 1994. Setup and relaxation in glacial sand. J. Geotech. Eng. 120, 1498-1513.

[32] Reddy, S.C., Stuedlein, A.W. (2014) Reddy and Stuedlein (2014) Time dependant capacity Increase of piles driven in the puget sound lowlands. Geo-congress from soil behavior fundamentals to innovations in Geotechnical Engineering. https://doi.org/10.1061/9780784413265.037.

[33] Long, J.H., Kerrigan, J.A., Wysockey, M.H. (1999) Measured Time Effects for Axial Capacity of Driven Piling. Transportation Research Record 1663, Paper No. 99-1183, pp. 8-15.

[34] Rimoy, S., Silva, M. Jardine, R., Yang, Z. X., Zhu, B. T., Tsuha C. H. C. (2015) Field and model investigations into the influence of age on axial capacity of displacement piles in silica sands, Géotechnique, Vol. 65, Issue 7, pp. 576-589.

[35] Rimoy, S. P., Jardine, R. J. (2015) Analysis of an extended field test database regarding drivenpile ageing in sands. Geotechnical Engineering for Infrastructure and Development: XVI European Conference on Soil Mechanics and Geotechnical Engineering ISBN: 978-0-7277-6067-8 